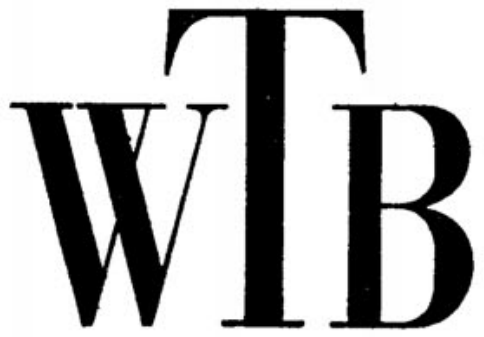

Chemie

WISSENSGHAFTLICHE TASCHENBÜCHER

咨

\title{
SIEGFRIED HAUPTMANN
}

\author{
Über den Ablauf \\ organisch-chemischer \\ Reaktionen
}


